\title{
RESEARCH PAPER \\ Genetic variability in vegetable Chenopodium for morphological and quality traits over different cuttings
}

\author{
Atul Bhargava', ${ }^{1,2}$ Francisco Fuentes ${ }^{3}$, Sudhir Shukla ${ }^{2}$, Shilpi Srivastava ${ }^{1}$, \\ Saijasi Dubey ${ }^{1}$, and Deepak Ohri ${ }^{2,4}$ \\ ${ }^{1}$ Amity University Uttar Pradesh (Lucknow Campus), Amity Institute of Biotechnology. Lucknow 226028, \\ India. \\ ${ }^{2}$ National Botanical Research Institute, Division of Genetics and Plant Breeding. Lucknow-226001, India. \\ ${ }^{3}$ Pontificia Universidad Católica de Chile, Facultad de Agronomía e Ingeniería Forestal, Av. Vicuña \\ Mackenna 4860, Macul. Casilla 306-22, Santiago, Chile. \\ ${ }^{4}$ Amity University Uttar Pradesh (Lucknow Campus),Research Cell. Lucknow 226028, India.
}

\begin{abstract}
A. Bhargava, F. Fuentes, S. Shukla, S. Srivastava, S. Dubey, and D. Ohri. 2019. Genetic variability in vegetable Chenopodium for morphological and quality traits over different cuttings. Cien. Inv. Agr. 46(2): 179-186. The present study was performed to assess the genetic parameters for different quantitative and qualitative traits of 13 germplasm lines of Chenopodium spp. The lines were sown in a randomized block design with a plot size of $2 \mathrm{~m}^{2}$, and data were recorded for foliage yield and 8 component traits over 4 successive cuttings. The foliage yield/plot was variable, ranging from 1.07-2.66 tha ${ }^{-1}$ with an average yield of $2.00 \pm 0.15$. The protein and carotenoid contents averaged $3.70 \pm 0.09 \%$ and $13.47 \pm 0.56 \mathrm{mg} 100 \mathrm{~g}^{-1}$, respectively. The range and mean of individual cuttings for plant height, leaf size, protein and foliage yield increased with successive cuttings until the III $^{\text {rd }}$ cutting, and the yield declined thereafter. High heritability estimates for all the traits under study were obtained for individual cuttings as well as on a pooled basis. High heritability coupled with high genetic gain was observed for foliage yield, carotenoid content and protein content, indicating the presence of additive gene effects.
\end{abstract}

Keywords: Chenopodium, cuttings, foliage yield, genetic advance, heritability, protein.

\section{Introduction}

Underutilized or neglected crops are ancient plant species that have been used by local communities for a long time and have been maintained by cultural

Received Feb 18, 2019. Accepted Jun 04, 2019. Corresponding author: abhargava@amity.edu preferences and traditional practices (Mayes et al., 2011; Bhargava and Srivastava, 2013). These crops have played an important role in strengthening the food security, nutrition, and income generation of the rural poor in several countries worldwide. However, these crops have remained inadequately characterized and neglected in terms of research, extension services and conservation (Magbagbeola 
et al., 2010; Mayes et al., 2011). A number of other terms, such as orphan, minor, abandoned, lost, underused, local, promising, traditional, forgotten and alternative crops, are often used for these less utilized species (Padulosi and Hoeschle-Zeledon, 2004). The cultivation of these traditional crops has declined over time, yet many of these wild and underutilized plants have the potential for more widespread use and could contribute to agricultural diversification, income generation, food provision and nutritional security (Vietmeyer, 1986; Chivenge et al., 2015; Bhargava and Srivastava, 2013). These crops are more important than other commercially cultivated crops since they can be cultivated with low inputs and therefore provide economic and environmental benefits. It can be safely said that the new century will see renewed interest and utilization of these underutilized crops. In the last few decades, chenopods have shown potential as food crops for agricultural diversification due to their climate adaptability and nutritional superiority (Bhargava et al., 2010; Bhargava and Ohri, 2015).

The genus Chenopodium (family: Amaranthaceae), known as the goosefoot genus, comprises approximately 250 species (Giusti, 1970) and includes mostly facultatively autogamous annuals distributed in temperate regions of the Americas, Asia and Europe (Wilson, 1990; Jellen et al., 2011). Of the several species of the genus that have been used, only three, $C$. quinoa $(2 \mathrm{n}=36), C$. pallidicaule $(2 \mathrm{n}=18)$ and $C$. berlandieri ssp. nuttalliae $(2 \mathrm{n}=36)$, have been cultivated as food crops (Bhargava et al., 2010; Zurita-Silva et al., 2014). However, the leaves and tender stems of several other species of the genus are used as food and fodder (Facciola, 1990; Moerman, 1998; Partap et al., 1998; Bhargava et al., 2007a, 2008a, 2008b; Fuentes and Paredes-Gónzalez, 2015). Chenopods are a rich source of nutrients such as protein, vitamins and a wide range of minerals (Prakash et al., 1993; Bhargava et al., 2007a, 2007b; Miranda et al., 2012). Recently, chenopods have been on the forefront of research, especially as an alternative crop for agriculturally marginal lands and stressful environments in many parts of the world (Bhargava et al., 2003a, 2006; Fuentes et al., 2012; Bazile et al., 2016).

Although the crop is nutritionally very important, information on the genetic improvement of vegetable chenopods is scarce (Bhargava et al., 2003b, 2003c, 2007a, 2019) and is restricted to a single species, C. album. Improvement of foliage requires knowledge of the extent of genetic variability in the available germplasm, the interrelationships between different traits, the extent of the environmental effects on these characters, trait heritability and the potential genetic gain of the material (Bhargava et al., 2007b; Litrico and Violle, 2007; Pistorale et al., 2008). Surprisingly, this information is completely absent for numerous species of Chenopodium. To fill this gap, the present investigation was conducted to obtain in-depth knowledge of the different selection parameters for different quantitative and qualitative traits of vegetable Chenopodium.

\section{Materials and Methods}

The experiment was carried out in the experimental field of the CSIR-National Botanical Research Institute, Lucknow $\left(26.5^{\circ} \mathrm{N}\right.$ and $\left.80.5^{\circ} \mathrm{E}\right)$, situated at an altitude of 120 meters above mean sea level. The region has a subtropical climate characterized by long, hot summers, cool winters and a marked rainy season between these two seasons. In the northern part of India, Chenopodium is generally grown as a winter crop, when the temperature ranges from $2-29^{\circ} \mathrm{C}$. The experimental material for the present study comprised 13 germplasm lines of Chenopodium spp. (Table 1), which included 7 lines of $C$. giganteum, 2 of $C$. murale and 1 each of C. bushianum, C. strictum, C. ugandae and $C$. opulifolium. These lines, obtained from different sources, have different ploidy levels and have been maintained for several years at the research institute.

The germplasm lines were sown in a randomized block design with 3 replications. The plot size for 
each treatment was $4 \mathrm{~m}^{2}$ with 6 rows per plot. The plant-to-plant distance was maintained at $30 \mathrm{~cm}$. Irrigation was provided as required, and hand weeding was periodically carried out. No chemical fertilizer or pesticide was used. A total of 4 cuttings were performed. The first cutting was carried out the $4^{\text {th }}$ week after sowing, and thereafter, three more cuttings were performed at intervals of 15 days. Foliage yield was recorded on a plot basis for different cuttings in $\mathrm{kg} / \mathrm{plot}$ and then converted to $t \mathrm{ha}^{-1}$. Observations were recorded for each cutting of 10 randomly selected plants in each replication for five morphological traits, namely, plant height $(\mathrm{cm})$, leaves per plant, leaf size $\left(\mathrm{cm}^{2}\right)$, branches per plant and stem diameter (cm). Fresh leaves of each cutting were analyzed separately for three qualitative traits, namely, moisture (\%), carotenoid content (mg $100 \mathrm{~g}^{-1}$ ) and protein content $(\%)$. Qualitative data were collected from randomly selected samples for all 4 cuttings separately. Moisture content was estimated as the ratio of fresh leaf weight to 100 ${ }^{\circ} \mathrm{C}$ dry weight. The extraction and estimation of leaf carotenoid and leaf protein contents were carried out per the methods suggested by Jensen (1978) and Lowry et al. (1951), respectively.

The data were subjected to statistical analysis of variance according to Panse and Sukhatme (1978). The phenotypic and genotypic coefficients of variation (PCV and GCV), heritability in broad sense (\%) and genetic advance (\%) were calculated according to the methods outlined by Singh and Chaudhary (1985) and Johnson et al. (1955).

\section{Results and Discussion}

The analysis of variance (ANOVA) revealed significant differences in the germplasm for individual cuttings and traits, except for branches per plant and moisture content in the IV ${ }^{\text {th }}$ cutting (Table 2). The foliage yield was variable, ranging from 1.07-2.66 $\mathrm{t} \mathrm{ha}^{-1}$, with an average yield of $2.00 \pm 0.15$ (Table 2). Plant height ranged from $12.89-22.40 \mathrm{~cm}$ with an average of $15.97 \pm 1.68$, while branches per plant ranged from 7.76-12.65, with a mean of $9.39 \pm 0.60$. The leaf size and number of leaves per plant ranged from $16.35-35.90 \mathrm{~cm}^{2}$ and $10.20-28.94$, with average values of $27.94 \pm 2.96$ and $17.28 \pm 3.25$, respectively. The stem diameter ranged from $0.37-0.51 \mathrm{~cm}$ with a mean of $0.46 \pm 0.03$. Among the quality traits, carotenoid and protein content ranged from 12.12-

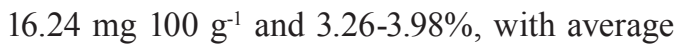
values of $13.47 \pm 0.56$ and $3.70 \pm 0.09$, respectively. Leaf moisture was in the range of 78.23-85.48\%, with an average of $81.00+1.22$.

The range and mean of individual cuttings for leaves per plant increased with increasing cuttings and were highest in the IV ${ }^{\text {th }}$ cutting (Table 2), while the plant height, leaf size, protein and

Table 1. Germplasm lines, ploidy levels, chromosome numbers and origins.

\begin{tabular}{lcccc}
\hline S.No & Germplasm lines & $\begin{array}{c}\text { Accession } \\
\text { number }\end{array}$ & 2n & Source \\
\hline 1. & C. giganteum D. Don & CHEN 86/85 & 54 & IPK Gatersleben, Germany \\
2. & C. giganteum D. Don & CHEN 32/78 & 54 & IPK Gatersleben, Germany \\
3. & C. giganteum D. Don & Ames 19046 & 54 & USDA \\
4. & C. giganteum D. Don & Ames 86650 & 54 & USDA \\
5. & C. giganteum D. Don & PI 596371 & 54 & USDA \\
6. & C. giganteum D. Don & PI 596372 & 54 & USDA \\
7. & C. giganteum D. Don & local & 54 & India \\
8. & Chenopodium murale L. & CHEN 48/82 & 18 & IPK Gatersleben, Germany \\
9. & Chenopodium murale L. & local & 18 & India \\
10. & Chenopodium bushianum Allen & Ames 22376 & 54 & USDA \\
11. & Chenopodium strictum Roth. & CHEN 47/79 & 54 & IPK Gatersleben, Germany \\
12. & Chenopodium ugandae (Aell.) Aell. & CHEN 77/78 & 36 & IPK Gatersleben, Germany \\
13. & Chenopodium opulifolium Schrad. ex DC. & CHEN 43/96 & & IPK Gatersleben, Germany \\
\hline
\end{tabular}


Table 2. Genetic variability, heritability and genetic advance for various traits in different cuttings in Chenopodium spp.

\begin{tabular}{|c|c|c|c|c|c|c|c|c|c|c|c|c|}
\hline Traits & Cuttings & $F$ value & Mean $\pm \mathrm{SE}$ & Range & $\sigma^{2} \mathrm{p}$ & $\sigma^{2} g$ & $\sigma^{2} \mathrm{e}$ & PCV & $\mathrm{GCV}$ & $\begin{array}{c}\text { Heritability } \\
(\%)\end{array}$ & $\begin{array}{l}\text { Genetic } \\
\text { advance }\end{array}$ & $\begin{array}{c}\text { Genetic } \\
\text { advance } \\
(\%)\end{array}$ \\
\hline Plant & I & 6.92 & $11.92+0.30$ & $7.10-15.49$ & 9.84 & 7.74 & 2.10 & 26.32 & 23.34 & 78.66 & 5.08 & 42.62 \\
\hline height & II & 4.66 & $14.60+0.73$ & $10.82-18.15$ & 23.00 & 19.40 & 3.60 & 32.85 & 30.17 & 84.35 & 8.33 & 57.05 \\
\hline \multirow[t]{3}{*}{$(\mathrm{cm})$} & III & 3.99 & $19.41+1.09$ & $11.70-26.10$ & 37.56 & 30.15 & 7.41 & 31.57 & 28.29 & 81.27 & 10.13 & 52.19 \\
\hline & IV & 4.80 & $17.96+1.14$ & $13.36-24.55$ & 41.40 & 34.50 & 6.90 & 35.69 & 32.70 & 83.33 & 11.04 & 61.47 \\
\hline & $P$ & - & $15.97+1.68$ & $12.89-22.40$ & 11.27 & 7.21 & 4.06 & 21.02 & 16.81 & 63.97 & 4.42 & 27.68 \\
\hline \multirow{5}{*}{$\begin{array}{l}\text { Leaves } \\
\text { /plant }\end{array}$} & I & 5.16 & $9.63+0.39$ & $6.94-16.45$ & 10.40 & 8.45 & 1.95 & 33.49 & 30.18 & 81.25 & 5.40 & 56.07 \\
\hline & II & 9.42 & $14.16+0.87$ & $11.79-19.10$ & 17.39 & 14.19 & 3.20 & 29.45 & 26.60 & 81.60 & 7.01 & 49.50 \\
\hline & III & 12.65 & $22.40+1.96$ & $17.34-29.00$ & 25.17 & 19.55 & 5.62 & 22.40 & 19.74 & 77.67 & 8.03 & 35.85 \\
\hline & IV & 4.89 & $22.94+1.40$ & $19.49-34.13$ & 21.60 & 18.34 & 3.26 & 20.26 & 18.67 & 84.91 & 8.13 & 35.44 \\
\hline & $P$ & - & $17.28+3.25$ & $10.20-28.94$ & 5.25 & 3.26 & 1.99 & 13.26 & 10.45 & 62.02 & 2.93 & 0.17 \\
\hline \multirow{5}{*}{$\begin{array}{l}\text { Leaf } \\
\text { size }\left(\mathrm{cm}^{2}\right)\end{array}$} & I & 9.02 & $20.57+1.43$ & $13.60-24.52$ & 20.29 & 18.19 & 2.10 & 21.90 & 20.73 & 98.65 & 7.64 & 37.14 \\
\hline & II & 4.57 & $26.91+1.71$ & $21.29-30.17$ & 40.50 & 33.36 & 7.14 & 23.65 & 21.46 & 82.37 & 10.80 & 40.13 \\
\hline & III & 6.11 & $34.85+1.39$ & $24.85-39.50$ & 46.55 & 36.45 & 10.10 & 19.58 & 17.32 & 78.30 & 11.00 & 31.56 \\
\hline & IV & 5.19 & $29.42+2.02$ & $20.92-34.47$ & 35.64 & 29.14 & 6.50 & 20.29 & 18.35 & 81.76 & 10.05 & 34.16 \\
\hline & $P$ & - & $27.94+2.96$ & $16.35-35.90$ & 20.25 & 15.15 & 5.10 & 16.10 & 13.93 & 74.81 & 6.93 & 24.8 \\
\hline \multirow{5}{*}{$\begin{array}{l}\text { Branches } \\
\text { /plant }\end{array}$} & I & 12.00 & $7.59+0.34$ & $6.12-8.99$ & 11.22 & 6.32 & 4.90 & 44.13 & 33.12 & 56.33 & 3.89 & 51.25 \\
\hline & II & 7.15 & $10.18+0.83$ & $6.55-12.34$ & 10.29 & 8.11 & 2.18 & 31.51 & 27.97 & 78.81 & 5.21 & 51.18 \\
\hline & III & 4.22 & $9.82+0.79$ & $5.19-11.67$ & 5.73 & 4.82 & 0.91 & 24.38 & 22.36 & 84.12 & 4.15 & 42.26 \\
\hline & IV & NS & $9.96+0.34$ & $5.82-12.44$ & 6.20 & 5.07 & 1.13 & 25.00 & 22.61 & 81.77 & 4.19 & 42.07 \\
\hline & $P$ & - & $9.39+0.60$ & $7.76-12.65$ & 1.91 & 1.10 & 0.81 & 14.72 & 11.17 & 75.88 & 2.16 & 23.00 \\
\hline \multirow{5}{*}{$\begin{array}{l}\text { Stem diameter } \\
(\mathrm{cm})\end{array}$} & I & 8.19 & $0.42+0.06$ & $0.31-0.48$ & 0.04 & 0.01 & 0.03 & 47.62 & 23.81 & 25.00 & 0.10 & 23.81 \\
\hline & II & 5.66 & $0.40+0.04$ & $0.33-0.48$ & 0.06 & 0.04 & 0.02 & 61.24 & 50.00 & 66.67 & 0.34 & 85.00 \\
\hline & III & 7.03 & $0.49+0.05$ & $0.38-0.54$ & 0.05 & 0.03 & 0.02 & 45.63 & 35.35 & 60.00 & 0.28 & 57.14 \\
\hline & IV & 14.60 & $0.53+0.05$ & $0.41-0.59$ & 0.07 & 0.04 & 0.03 & 49.92 & 37.73 & 57.14 & 0.31 & 58.49 \\
\hline & $P$ & - & $0.46+0.03$ & $0.37-0.51$ & 0.004 & 0.001 & 0.003 & 13.75 & 6.87 & 49.96 & 0.06 & 13.04 \\
\hline \multirow{5}{*}{$\begin{array}{l}\text { Moisture } \\
(\%)\end{array}$} & I & 13.65 & $80.76+7.80$ & $76.58-84.98$ & 6.57 & 5.14 & 1.43 & 3.17 & 2.81 & 78.23 & 4.13 & 5.11 \\
\hline & II & 10.40 & $84.43+9.44$ & $77.54-85.90$ & 26.91 & 14.90 & 12.01 & 6.14 & 4.57 & 55.37 & 5.92 & 7.01 \\
\hline & III & 11.81 & $80.12+7.39$ & $77.19-83.00$ & 13.17 & 8.81 & 4.36 & 4.53 & 3.70 & 66.89 & 5.00 & 6.24 \\
\hline & IV & NS & $78.70+3.21$ & $76.38-80.64$ & 9.66 & 7.24 & 2.42 & 3.95 & 3.42 & 74.95 & 4.80 & 6.10 \\
\hline & $\mathrm{P}$ & - & $81.00+1.22$ & $78.23-85.48$ & 23.59 & 18.89 & 4.70 & 6.00 & 5.36 & 80.08 & 8.01 & 9.89 \\
\hline \multirow{5}{*}{$\begin{array}{l}\text { Carotenoid (mg } \\
100 \mathrm{~g}^{-1} \text { ) }\end{array}$} & I & 6.17 & $13.52+1.20$ & $10.90-15.65$ & 14.06 & 9.86 & 4.20 & 27.73 & 23.22 & 70.13 & 5.42 & 40.09 \\
\hline & II & 4.73 & $14.94+1.57$ & $12.48-16.41$ & 16.10 & 12.48 & 3.62 & 26.86 & 23.64 & 77.51 & 6.41 & 42.90 \\
\hline & III & 8.60 & $13.18+1.23$ & $12.03-13.92$ & 17.35 & 13.44 & 3.91 & 31.6 & 27.81 & 77.46 & 6.65 & 50.45 \\
\hline & IV & 5.09 & $12.26+1.01$ & $11.30-12.65$ & 14.67 & 12.19 & 2.48 & 31.24 & 28.48 & 83.09 & 6.55 & 53.42 \\
\hline & $\mathrm{P}$ & - & $13.47+0.56$ & $12.12-16.24$ & 18.70 & 12.50 & 6.20 & 32.10 & 26.25 & 66.84 & 5.95 & 44.17 \\
\hline \multirow{5}{*}{$\begin{array}{l}\text { Protein } \\
(\%)\end{array}$} & I & 7.54 & $3.49+0.49$ & $2.96-3.70$ & 4.42 & 2.50 & 1.92 & 60.24 & 45.30 & 56.56 & 2.45 & 70.20 \\
\hline & II & 9.88 & $3.63+0.41$ & $3.18-3.82$ & 3.53 & 3.08 & 0.45 & 51.76 & 48.35 & 88.00 & 3.40 & 93.66 \\
\hline & III & 4.54 & $3.92+0.32$ & $3.64-4.09$ & 3.12 & 1.98 & 0.14 & 45.06 & 35.90 & 63.46 & 2.31 & 58.93 \\
\hline & IV & 4.98 & $3.75+0.43$ & $3.59-3.86$ & 1.71 & 1.09 & 0.62 & 34.87 & 27.84 & 63.74 & 1.72 & 45.87 \\
\hline & $P$ & - & $3.70+0.09$ & $3.26-3.98$ & 0.86 & 0.62 & 0.24 & 25.06 & 21.28 & 84.92 & 1.62 & 43.78 \\
\hline \multirow{5}{*}{$\begin{array}{l}\text { Foliage yield } \\
\left(t \mathrm{tha}^{-1}\right)\end{array}$} & I & 7.69 & $1.58+0.19$ & $1.14-1.73$ & 0.92 & 0.74 & 0.18 & 60.71 & 54.44 & 80.43 & 1.59 & 100.63 \\
\hline & II & 5.82 & $2.10+0.43$ & $1.49-2.25$ & 0.36 & 0.26 & 0.10 & 28.57 & 24.28 & 72.22 & 0.89 & 42.38 \\
\hline & III & 6.91 & $2.28+0.26$ & $1.96-2.89$ & 0.69 & 0.48 & 0.21 & 36.43 & 30.39 & 69.56 & 1.19 & 52.19 \\
\hline & IV & 5.57 & $2.03+0.33$ & $1.82-2.44$ & 0.81 & 0.58 & 0.23 & 44.33 & 37.52 & 71.6 & 1.33 & 65.52 \\
\hline & $\mathrm{P}$ & - & $2.00+0.15$ & $1.07-2.66$ & 0.97 & 0.69 & 0.28 & 49.24 & 41.53 & 71.13 & 1.44 & 72.00 \\
\hline
\end{tabular}

$\sigma^{2} \mathrm{~g}=$ Genotypic variance, $\sigma^{2} \mathrm{p}=$ Phenotypic variance, $\sigma^{2} \mathrm{e}=$ Environmental variance, $\mathrm{PCV}=$ Phenotypic coefficient of variation, $\mathrm{GCV}=$ Genotypic coefficient of variation

foliage yield values increased with each cutting until the III ${ }^{\text {rd }}$ cutting. However, the values for these traits decreased after the III ${ }^{\text {rd }}$ cutting.

The present study clearly indicates that the species assessed can serve as potential vegetable crops due to their high biomasses and ample amounts of proteins and carotenoids. The protein content, though lower than that of the commonly used foliage crop C. album (Prakash et al., 1993; Bhargava et al., 2007a), was higher than those reported for amaranth (Shukla et al., 2003) and spinach (Kuti and Kuti, 1999). Likewise, the material contained appreciable amounts of carotenoids, with levels 
higher than that of C. album. These species seem to have more regeneration capacity in comparison to C. album, since 4 cuttings were performed for the species in this study, whereas a maximum of 3 cuttings have been reported for $C$. album by Bhargava et al. (2003a). Thus, there is a need to further explore the potential of these underutilized species of Chenopodium for use as fodder crops and for human consumption.

The estimates of variance, phenotypic coefficient of variation (PCV), genotypic coefficient of variation (GCV), heritability in broad sense and genetic advance are shown in Table 2. The PCV had higher estimates than the corresponding GCV for all the characteristics, and in most cases, the two values differed only slightly. The small difference between PCV and GCV for all the traits except stem diameter indicates that the variability was primarily due to genotypic differences. Foliage, followed by plant height and leaf size among the morphological traits, and carotenoid and protein content among the quality traits exhibited high PCV and GCV values, which indicates the potential for improvement of these traits through selection to enhance the potentiality of foliage yield. A high coefficient of variability for foliage yield has previously been reported in other foliage crops, such as vegetable amaranth (Shukla and Singh, 2000) and C. album (Bhargava et al., 2003b). However, the lower estimates for one or both of these parameters observed for the rest of the traits implies that the chances of obtaining substantial gain under selection are likely to be lower for these traits.

It is difficult to determine the amount of the variation that is heritable merely based on the extent of the coefficient of variation values. Knowledge of the heritability of a trait is important because it indicates the amount of advance to be expected through phenotypic selection (Robinson et al., 1949; Burton and DeVane, 1953). Heritability, the proportion of the individual differences in a trait due to genetic difference, has been extensively utilized as an effective tool to assess the degree to which a trait is transmitted from parent to progeny (Piepho and Möhring, 2007). This important parameter in quantitative genetics also indicates the relative importance of heredity and environment in the expression of these traits. Narrow-sense heritability (designated as $h^{2}$ ) is the ratio of additive genetic variance to the total phenotypic variance and includes only the additive effects of variation (Nishio et al., 2014). In the present investigation, the heritability estimates were high for all the traits in most cuttings individually as well as on a pooled basis, which suggests that all of the variability in traits comes from genetic differences. High heritability values have also been obtained for different foliage cuttings of lamb's quarters (Bhargava et al., 2003a; Basavaraj et al., 2018) and Amaranthus tricolor (Shukla et al., 2004).

High heritability alone does not guarantee a large improvement from selection unless sufficient genetic gain attributable to additive gene action is present (Mora and Saavedra, 2012). Genetic advance in a trait is the product of the heritability and selection differential, expressed in units of standard deviation, and has an added advantage over heritability as a guiding factor in a selection program where improvement in particular traits is desired (Xu et al., 2017; Li et al., 2018). The expected genetic advance, expressed as a percentage of the mean, was lowest for leaves per plant, moisture and stem diameter, which indicates the presence of non-additive gene effects; hence, these traits are unlikely to respond favorably to selection. In contrast, foliage yield, carotenoid content and protein content had high values for genetic advance $(72.00,44.17$ and $43.78 \%$, respectively). These traits also had high heritability and high coefficients of variability, indicating that the genotypic variance for these characters was due to additive gene effects. Hence, the selection based on the phenotypic performance for these characters would be beneficial for achieving the desired gain. 


\section{Conclusion}

From the present study, it was concluded that many species of Chenopodium could be utilized as vegetables with high protein and carotenoid contents. Significant enhancements in foliage yield and foliage quality traits can be achieved through rigorous selection of plant types based on the component traits.

\section{Acknowledgements}

Atul Bhargava is grateful to CSIR for the fellowship and to the Director of CSIR-NBRI for providing the necessary facilities to carry out the present investigation.

\title{
Resumen
}

\begin{abstract}
A. Bhargava, F. Fuentes, S. Shukla, S. Srivastava, S. Dubey, y D. Ohri. 2019. Variabilidad genética en el Chenopodium vegetal para rasgos morfológicos y de calidad sobre diferentes esquejes. Cien. Agr. 46(2): 179-186. El presente estudio se realizó para evaluar los parámetros genéticos de diferentes rasgos cuantitativos y cualitativos de 13 líneas de germoplasma de Chenopodium spp. sembradas en un diseño de bloques aleatorios con un tamaño de parcela de 2 $\mathrm{m} 2$, y se registraron datos de rendimiento foliar y 8 rasgos componentes en 4 esquejes sucesivos. El rendimiento foliar/parcela fue variable, oscilando entre 1,07-2,66 $\mathrm{t} \mathrm{ha}^{-1}$ con un rendimiento medio de $2,00 \pm 0,15$. El contenido de proteínas y carotenoides promedió $3.70 \pm 0.09 \%$ y

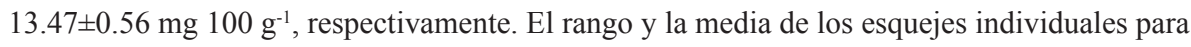
la altura de la planta, el tamaño de la hoja, la proteína y el rendimiento foliar aumentaron con esquejes sucesivos hasta el III corte, y el rendimiento disminuyó posteriormente. Se obtuvieron estimaciones de alta heredabilidad para todos los rasgos bajo estudio, tanto para cortes individuales como sobre una base combinada. Se observó una alta heredabilidad junto con una alta ganancia genética en el rendimiento foliar, el contenido de carotenoides y el contenido de proteínas, lo que indica la presencia de efectos genéticos aditivos.
\end{abstract}

Palabras clave: Avance genético, chenopodium, esquejes, heredabilidad, proteína, rendimiento foliar.

\section{References}

Basavaraj, C.N., Hanchinamani, S.J. Imamsaheb, H.P. Hadimani, and S.H. Ramanagouda. 2018. Genetic variability studies among various morphological and quality traits in bathua (Chenopodium album L.). International Journal of Current Microbiology and Applied Biosciences 7:4147-4151

Bazile, D., S.E. Jacobsen, and A. Verniau. 2016. The global expansion of quinoa: trends and limits. Frontiers in Plant Science 7:622.

Bhargava, A., and D. Ohri. 2015. Quinoa in the Indian subcontinent. In: 'FAO and CIRAD: State of the
Art Report of Quinoa in the World in 2013' (Eds. Bazile et al.). FAO, Rome, Italy. pp:511-523.

Bhargava, A., S. Shukla, R.S. Katiyar, and D. Ohri. 2003a. Selection parameters for genetic improvement in Chenopodium grain in sodic soil. Journal of Applied Horticulture 5:45-48.

Bhargava, A., S. Shukla, and D. Ohri. 2003b. Genetic variability and heritability of selected traits during different cuttings of vegetable Chenopodium. Indian Journal of Genetics and Plant Breeding 63:359-360.

Bhargava, A., S. Shukla, and D. Ohri. 2003c. Relative selection efficiency for foliage yield and quality characters in vegetable Chenopodium 
over different cuttings. Journal of Applied Horticulture 5:85-86.

Bhargava, A., S. Shukla, and D. Ohri. 2006. Chenopodium quinoa- an Indian perspective. Industrial Crops and Products 23:73-87.

Bhargava, A., S. Shukla, and D. Ohri. 2007a. Evaluation of foliage yield and leaf quality traits in Chenopodium spp. in multiyear trials. Euphytica 153:199-213.

Bhargava, A., S. Shukla, and D. Ohri. 2007b. Genetic variability and interrelationship among various morphological and quality traits in quinoa (Chenopodium quinoa Willd.). Field Crops Research 101:104-116.

Bhargava, A., S. Shukla, J. Srivastava, N. Singh, and D. Ohri 2008a. Genetic diversity for mineral accumulation in foliage of Chenopodium spp. Scientia Horticulturae 118:338-346.

Bhargava, A., S. Shukla, and D. Ohri. 2008b. Genotype $\mathrm{x}$ environment interaction studies in Chenopodium album L.: an underutilized crop with promising potential. Communications in Biometry and Crop Science 3:3-15.

Bhargava, A., S. Shukla, and D. Ohri. 2010. Mineral composition in foliage of some cultivated and wild species of Chenopodium. Spanish Journal of Agricultural Research 8:371-376.

Bhargava, A. and S. Srivastava. 2013. Quinoa: Botany, Production and Uses. CABI, UK.

Bhargava, A., F. Fuentes, S. Shukla, S. Srivastava, and D. Ohri. 2019. Genetic association between foliage yield and contributing traits in vegetable chenopods: implications for genetic improvement. Notulae Botanicae Horti Agrobotanici Cluj-Napoca 47:24-33.

Burton, G.W., and E.H. DeVane. 1953. Estimations of heritability in tall festca (Festuca arundinacea) from replicated clonal materials. Agronomy Journal 45:478-481.

Chivenge, P., T. Mabhaudhi, A.T. Modi, and P. Mafongoya. 2015. The potential role of neglected and underutilised crop species as future crops under water scarce conditions in sub-Saharan Sfrica. International Journal of Environmental Research and Public Health 12:5685-5711.

Facciola, S. 1990. Cornucopia - A Source Book of
Edible Plants. Kampong Publications, CA.

Fuentes, F., D. Bazile, A. Bhargava, and E.A. Martinez. 2012. Implications of farmers' seed exchanges for on-farm conservation of quinoa, as revealed by its genetic diversity in Chile. Journal of Agricultural Sciences (Cambridge) 150:702-716.

Fuentes, F., and X. Paredes-Gónzalez. 2015. Nutraceutical perspectives of quinoa: biological properties and functional applications. In: Bazile et al. (Eds). FAO and CIRAD: state of the art report of quinoa in the world in 2013. FAO, Rome, Italy pp:286-299.

Giusti, L. 1970. El genero Chenopodium en Argentina 1: Numeros de cromosomas. Darwiniana 16:98-105.

Jellen, E.N., B.A. Kolano, M.C. Sederberg, A. Bonifacio, and P.J. Maughan. 2011. Chenopodium. In: Kole, C. (ed.), Wild Crop Relatives: Genomic and Breeding Resources, Legume Crops and Forages. Springer-Verlag, Berlin Heidelberg, Germany, pp:35-61.

Jensen, A. 1978. Chlorophylls and carotenoids. In: Hellebust, J.A., Craigie, J.S., (Eds.), Handbook of Physiological Methods: Physiological and Biochemical Methods, Cambridge University Press, Cambridge, pp:5-70.

Johnson, H.W., H.F. Robinson, and R.E. Comstock. 1955. Estimates of genetic and environmental variability in soybean. Agronomy Journal 47:314-318.

Kuti, J.O., and H.O. Kuti. 1999. Proximate composition and mineral content of two edible species of Cnidoscolus (tree spinach). Plant Foods for Human Nutrition 53:275-283.

Li, H., A. Rasheed, L.T. Hickey, and Z. He. 2018. Fast-forwarding genetic gain. Trends in Plant Science 23:184-186.

Litrico, I., and C. Violle. 2007. Diversity in plant breeding: a new conceptual framework. Trends in Plant Science 20:604-613.

Lowry, O.H., N.J. Rosebrough, A.L. Farr, and R.J. Randal. 1951. Protein measurement with the Folin phenol reagent. Journal of Biological Chemistry 193:265-275.

Magbagbeola, J.A.O., J.A. Adetoso, and O.A. Owolabi. 2010. Neglected and underutilized species (NUS): a panacea for community focused development to poverty alleviation/poverty re- 
duction in Nigeria. Journal of Economics and International Finance 2:208-211.

Mayes, S., F.J. Massawe, P.G. Alderson, J.A. Roberts, S.N. Azam-Ali, and M. Hermann. 2011 The potential of underutilized crops to improve security of food production. Journal of Experimental Botany 63:1075-1079.

Miranda, M., A. Vega-Gálvez, E. Martinez, J. López, M.-J. Rodríguez, K. Henríquez, and F. Fuentes. 2012. Genetic diversity and comparison of physicochemical and nutritional characteristics of six quinoa (Chenopodium quinoa willd.) genotypes cultivated in Chile. Food Science and Technology 32:835-843.

Moerman, D. 1998. Native American Ethnobotany. Timber Press. Oregon.

Mora, F., and J. Saavedra 2012. Combining genetic gain and diversity under an individual selection method in a selected provenance of Eucalyptus cladocalyx. Ciencia e Investigación Agraria 39:177-184.

Nishio, S., M. Yamada, N. Takada, H. Kato, N. Onoue, Y. Sawamura, and T. Saito. 2014. Environmental variance and broad-sense heritability of nut traits in Japanese chestnut breeding. HortScience 49:696-700.

Padulosi, S., and I. Hoeschle-Zeledon. 2004. Underutilized plant species: what are they? LEISA 20:5-6.

Panse, V.G., and P.V. Sukhatme. 1978. Statistical methods for Agricultural Workers. ICAR, New Delhi.

Partap, T., B.D. Joshi, and N.W. Galwey. 1998. Chenopods: Chenopodium spp. promoting the conservation and use of underutilized and neglected crops. Institute of Plant Genetics and Crop Plant Research, Gatersleben, Rome, Italy.

Piepho, H.P., and J. Möhring. 2007. Computing heritability and selection response from unbalanced plant breeding trials. Genetics 177:1881-1888.

Pistorale, S.M., L.A. Abbott, and A. Andres. 2008. Genetic diversity and broad sense heritability in tall wheatgrass (Thinopyrum ponticum). Ciencia e Investigación Agraria 35:259-264.

Prakash, D., P. Nath, and M. Pal. 1993. Composition, variation of nutritional contents in leaves, seed protein, fat and fatty acid profile of Chenopodium species. Journal of the Sciences of Food and Agriculture 62:203-205.

Robinson, H.F., R.E. Comstock, and P.H. Harvey. 1949. Estimates of heritability and the degree of dominance in corn. Agronomy Journal 41:353-359.

Shukla, S., V. Pandey, G. Pachauri, B.S. Dixit, R. Banerji, and S.P. Singh, 2003. Nutritional contents of different foliage cuttings of vegetable amaranth. Plant Foods for Human Nutrition 58:1-8.

Shukla, S., and S.P. Singh. 2000. Studies on genetic parameters in vegetable amaranth. Journal of Genetics and Breeding 54:133-135.

Shukla, S., S.P. Singh, A. Bhargava, A. Chatterjee, and S.P. Singh. 2004. Estimates of genetic parameters to determine variability for foliage yield and its different quantitative and qualitative traits in vegetable amaranth (A. tricolor). Journal of Genetics and Breeding 58:169-176.

Singh, R.K., and B.D. Chaudhary. 1985. Biometrical Methods in Quantitative Genetic Analysis. Kalyani Publishers, New Delhi.

Vietmeyer, N.D. 1986. Lesser-known plants of agricultural use in agriculture and forestry. Science 232:1379-1384.

Wilson, H.D. 1990. Quinua and relatives (Chenopodium sect. Chenopodium subsect. Cellulata. Economic Botany 44: 92-110.

Xu, Y., P. Li, C. Zou, Y. Lu, C. Xie, X. Zhang, B.M. Prasanna, and M.S. Olsen. 2017. Enhancing genetic gain in the era of molecular breeding. Journal of Experimental Botany 68:2641-2666.

Zurita-Silva, A., F. Fuentes, P. Zamora, S.E. Jacobsen, and A. R. Schwember. 2014. Breeding quinoa (Chenopodium quinoa Willd.): potential and perspectives. Molecular Breeding 34:13-30. 